\title{
MODEL KRIMINALISASI BERBASIS KERUGIAN LINGKUNGAN DAN AKTUALISASINYA DALAM UNDANG-UNDANG 32 TAHUN 2009 TENTANG PERLINDUNGAN DAN PENGELOLAAN LINGKUNGAN HIDUP
}

\section{CRIMINALIZATION OF ENVIRONMENTAL HARM IN THE LAW NUMBER 32 YEAR 2009 ON ENVIRONMENTAL PROTECTION AND MANAGEMENT}

\author{
Mahrus Alia
}

\begin{abstract}
ABSTRAK
$\mathrm{P}$ enelitian ini bertujuan menganalisis diskursus teoritik tentang kriminalisasi berbasis kerugian lingkungan hidup dan aktualisasinya dalam Undang-Undang Perlindungan dan Pengelolaan Lingkungan Hidup. Sebagai penelitian hukum normatif dengan menggunakan pendekatan perundangundangan dan konseptual, penelitian ini menyimpulkan bahwa diskursus teoritik tentang model-model kriminalisasi berbasis kerugian lingkungan hidup mengacu kepada empat model yang selama ini berkembang, yaitu model bahaya abstrak, bahaya nyata, kerugian nyata, dan polusi lingkungan yang serius. Pada ketiga model pertama, hukum pidana masih belum melepaskan diri dari ketergantung administratif), sedangkan pada model terakhir, hukum pidana sudah melepaskan diri dari ketergantungan administratif. Hukum pidana tetap dapat digunakan apabila menimbulkan kerugian sangat serius sekalipun perbuatan tidak melawan hukum. Keempat model kriminalisasi tersebut teraktualisasi dalam UU PPLH. Penelitian ini merekomendasikan perlunya riset tentang aktualisasi model-model kriminalisasi berbasis kerugian lingkungan dalam perundang-undangan sektoral bidang lingkungan hidup.
\end{abstract}

Kata kunci: kriminalisasi; kerugian lingkungan; UU PPLH.

\begin{abstract}
The objective of this study is to analyze the discourse on criminalization of environmental harm and its 1 actualization in the Law on Environmental Protection and Management. As normative legal research, it is conducted with statutory and conceptual approaches. This study concludes that there are four models of environmental harm-based criminalization that have been develop so far, namely: abstract and concrete endangerment, concrete harm, and serious environmental pollution model. On the first three models, criminal law has not released from administrative dependence. Whereas in the last model, criminal law has released from its administrative dependency. In this model, criminal law can be still used in case a very serious environmental harm has arisen, despite the act is not against the law. The four models of criminalization have been manifested in the Law on Environmental Protection and Management. This research suggests to conduct research on the actualization of the model in the Laws related to environment.
\end{abstract}

Keywords: criminalization; environmental harm; environmental protection and management.

\footnotetext{
a Fakultas Hukum Universitas Islam Indonesia, Jl. Taman Siswa No.158 Yogyakarta 55151, email: mahrus_ali@uii.ac.id.
} 


\section{PENDAHULUAN}

$\mathrm{T}$ erdapat dua tahapan di dalam mengkriminalisasi suatu perbuatan. Pertama adalah mendefinisikan objek atau kepentingan hukum yang hendak dilindungi oleh hukum pidana. Objek di sini diartikan sebagai hak-hak orang lain. Hak-hak ini berada di dalam wilayah filsafat politik sebelum direduksi menjadi hak dalam hukum positif. Hak ini dalam konteks lingkungan hidup dimaknai sebagai hak kolektif atas lingkungan yang sehat dan bersih. Tahapan kedua adalah menentukan jenis perbuatan yang dilarang dan diancam dengan sanksi pidana. ${ }^{1}$ Suatu perbuatan dikriminalisasi salah satunya karena perbuatan itu merugikan. ${ }^{2}$ Kerugian dapat berupa kerugian individual, kerugian sosial, kerugian negara atau kerugian lingkungan.

Kriminalisasi berbasis kerugian lingkungan erat dengan pemikiran yang menempatkan lingkungan hidup sebagai kepentingan hukum sebagai imbas dari pandangan bahwa manusialah yang harus mematuhi alam (lingkungan) dan sekaligus sebagai korban kejahatan (green victimology). ${ }^{3}$ Kriminalisasi yang demikian juga terkait dengan karakteristik hukum lingkungan yang mengakui hak generasi mendatang pada posisi yang sama dengan generasi masa lalu atau saat ini untuk menikmati dan mendapatkan akses terhadap lingkungan hidup yang sehat. ${ }^{4}$ Kerusakan dan/atau pencemaran lingkungan yang terjadi dan dirasakan generasi saat ini pada akhirnya berimbas dan dirasakan oleh generasi mendatang.

Perbuatan yang merugikan lingkungan perlu dikriminalisasi karena merupakan merampas, menafikan atau menghilangkan hak generasi saat ini dan mendatang untuk menikmati lingkungan yang bersih dan sehat seperti merusak fungsi ekologi dan kesehatan ekosistem dalam banyak cara. ${ }^{5}$ Kerugian lingkungan yang ditimbulkan dapat berupa (ancaman) terhadap rusak dan terdegradasinya ekosistem, punahnya spesies, perubahan cuaca

1 Tatjana Hörnle, 2016, "Theories of Criminalization”, Criminal Law and Philosophy, Vol. 10, hlm. 304. Paul McGorrery, 2018, "The Philosophy of Criminalization: A Review of Duff et al.'s Criminalization Series", Criminal Law and Philosophy, Vol. 12, hlm. 19.

2 Stuart P. Green, 1997, “Why It's a Crime to Tear the Tag Off a Mattress; Overcriminalization and The Moral Content of Regulatory Offences", Emory Law Review, Vol. 46, hlm. 1549-1552.

3 Mary Christina Wood, 2014, Nature's Trust Environmental Law for a New Ecological Age, New York: Cambridge University Press, hlm. 6. Matthew Hall, “Environmental Harm and Environmental Victims Scooping Out a Green Victimology'”, International Review of Victimology, Vol. 20, hlm. 129-143.

4 Ben Boer, 1995, "Institutionalising Ecologically Sustainable Development: The Roles of National, State, and Local Governments in Translating Grand Strategy into Action", Willamette Law Review, Vol. 31, hlm. 319. Rowena Maguire, 2012, "Incorporating International Environmental Legal Principle into Future Climate Change", Carbon E Climate Law Review, Vol. 6, hlm. 105.

5 Todd S. Aagaard, 2011, "Environmental Harm, Use Conflicts, and Neutral Baselines in Environmental Law", Duke Law Journal, Vol. 60, , hlm. 1512. 
dan pemanasan global, polusi lingkungan, dan kematian binatang. ${ }^{6}$ Ketika lingkungan hidup rusak atau tercemar sehingga sulit atau bahkan tidak mungkin bisa diperbaiki, 7 ada kemungkinan besar generasi mendatang mengalami kematian akibat hal itu.

Meskipun kriminalisasi berbasis kerugian lingkungan penting dilakukan, tapi diskursus teoritik kriminalisasi yang berkembang masih bersifat umum dan belum menyentuh karakteristik delik lingkungan. Herbert L. Packer berfokus kepada kriteria imoralitas sebagai basis kriminalisasi, ${ }^{8}$ sedangkan Stuart Mill justru mengacu kepada kerugian individual. Negara hanya memiliki legitimasi untuk mengkriminalisasi suatu perbuatan sepanjang perbuatan tersebut merugikan orang lain. ${ }^{9}$ Douglas Husak menggagas teori pembatas internal dan eksternal kriminalisasi, ${ }^{10}$ sedangkan Nils Jareborg memperkenalkan prinsip-prinsip di dalam mengkriminalisasi suatu perbuatan sekalipun substansinya masih bersifat umum. ${ }^{11}$

Dalam konteks Undang-undang Nomor 32 Tahun 2009 tentang Perlindungan dan Pengelolaan Lingkungan Hidup (UUPPLH), perlunya kriminalisasi berbasis kerugian lingkungan didasarkan kepada beberapa alasan. Pertama, salah satu pertimbangan dibentuknya UU ini adalah didasarkan kepada fakta bahwa kualitas lingkungan hidup yang semakin menurun telah mengancam kelangsungan perikehidupan manusia dan makhluk hidup lainnya sehingga perlu dilakukan perlindungan dan pengelolaan lingkungan hidup yang sungguh- sungguh dan konsisten oleh semua pemangku kepentingan. Kedua, tujuan utama UU tersebut adalah mencegah timbulnya kerugian lingkungan baik berupa kerusakan atau pencemaran. Tujuan ini antara lain berbentuk perlindungan wilayah Negara Kesatuan Republik Indonesia dari pencemaran dan/atau kerusakan lingkungan hidup, jaminan keselamatan, kesehatan, dan kehidupan manusia, jaminan kelangsungan kehidupan makhluk hidup dan kelestarian ekosistem, dan jaminan terpenuhinya keadilan generasi masa kini dan generasi masa depan (Pasal 3 UUPPLH).

Ketiga, instrumen pencegahan pencemaran dan/atau kerusakan lingkungan hidup yang meliputi Kajian Lingkungan Hidup Strategis (KLHS), tata ruang, baku mutu lingkungan hidup, kriteria baku kerusakan lingkungan hidup, amdal, Upaya Pengelolaan Lingkungan dan

\footnotetext{
6 Jan G. Laitos, 2013, “Standing and Environmental Harm: The Double Paradox”, Virginia Environmental Law Journal, Vol. 31, hlm. 67-71.

7 Cass R. Sunstein, 2006, “Irreversible and Catastrophic”, Cornell Law Review, Vol. 91, hlm. 860-863.

8 Herbert L. Packer, 1968, The Limits of the Criminal Sanction, California: Stanford University Press, California, hlm. 262.

9 Salman Luthan, 2007, Kebijakan Penal Mengenai Kriminalisasi di Bidang Keuangan, Disertasi, Jakarta: Universitas Indonesia, hlm. 76-85.

${ }^{10}$ Douglas Husak, 2008, Overcriminalization the Limits of the Criminal Law, New York: Oxford University Press, hlm. 65-84.

${ }^{11}$ Nils Jareborg, 2005, 'Criminalization as Last Resort (ultima ratio)', Ohio State Journal of Criminal Law, hlm. 521-534.
} 
Upaya Pemantauan Lingkungan Hidup (UKL-UPL), perizinan, instrumen ekonomi lingkungan hidup, peraturan perundang-undangan berbasis lingkungan hidup, anggaran berbasis lingkungan hidup, analisis risiko lingkungan hidup, audit lingkungan hidup, dan instrumen lain sesuai dengan kebutuhan (Pasal 14 UU PPLH) adalah ditujukan untuk mencegah timbulnya kerugian lingkungan. Oleh karena itu, logis apabila kriminalisasi dalam UU PPLH diorientasikan kepada kerugian lingkungan.

Berdasarkan uraian pada latar belakang masalah di atas, permasalahan penelitian ini sebagai berikut; 1) bagaimanakah diskursus teoritik tentang model kriminalisasi berbasis kerugian lingkungan?; dan 2) bagaimana aktualisasi model kriminalisasi yang berbasis kerugian lingkungan dalam Undang-undang PPLH? Penelitian ini bertujuan untuk; 1) mengetahui dan menganalisis diskursus teoritik tentang model kriminalisasi berbasis kerugian lingkungan; dan 2) mengetahui, memetakan, dan menganalisis aktualisasi model kriminalisasi berbasis kerugian lingkungan dalam Undang-undang PPLH.

\section{METODE PENELITIAN}

Denelitian ini merupakan penelitian hukum normatif karena yang dikaji adalah teori dan
norma hukum dalam sistem perundang-undangan dengan memfokuskan pada diskursus teoritik tentang model kriminalisasi yang berorientasi kepada kerugian lingkungan baik secara teoritis maupun aktualisasinya dalam UU PPLH. ${ }^{12}$ Pendekatan yang digunakan adalah pendekatan konseptual dan perundang-undangan. ${ }^{13}$ Pendekatan konseptual mengacu kepada elemen-elemen konseptual (teoritis) kriminalisasi dan karakteristik hukum pidana lingkungan yang membentuk model-model kriminalisasi berbasis kerugian lingkungan, sedangkan pendekatan perundang-undangan diarahkan pada perbuatan-perbuatan yang dikriminalisasi dalam UU PPLH.

Bahan hukum dalam penelitian ini, yang dikumpulkan melalui studi literatur, berupa bahan hukum primer dan bahan hukum sekunder. Bahan hukum primer adalah UU PPLH terutama rumusan delik yang diatur mulai Pasal 98 hingga Pasal 115, sedangkan bahan hukum sekunder terkait literatur yang secara khusus berbicara tentang kriminalisasi, karakteristik hukum pidana lingkungan, dan kriminalisasi berbasis kerugian lingkungan. Bahan hukum

\footnotetext{
12Soetandyo Wigjnosoebroto, 2002, Hukum, Paradigma, Metode dan Dinamika Masalahnya, HuMa, Jakarta, hlm. 147150.

${ }^{13}$ Johny Ibrahim, 2006, Teori dan Metodologi Penelitian Hukum Normatif, Bayu Media Publishing, Malang, hlm. 320.
} 
tersebut kemudian dianalisis secara deskriptif kualitatif melalui reduksi bahan hukum, penyajian bahan hukum, dan penarikan kesimpulan. ${ }^{14}$

\section{PEMBAHASAN}

\section{Model Kriminalisasi Berbasis Kerugian Lingkungan}

K

riminalisasi terhadap suatu perbuatan umumnya didasarkan pada kerugian dan kepentingan hukum yang hendak dilindungi. Pertanyaan yang muncul dalam konteks hukum lingkungan adalah nilai dan kepentingan lingkungan apa yang hendak dilindungi dari dikriminalisasikannya suatu perbuatan? Jawaban atas pertanyaan ini merujuk kepada modelmodel kriminalisasi delik-delik lingkungan yang selama ini berkembang. Model dalam penelitian ini diartikan sebagai pola atau acuan untuk mengkriminalisasi perbuatan terkait aktivitas yang berpotensi atau menimbulkan kerusakan atau pencemaran lingkungan.

Diskursus teoritik kriminalisasi berbasis kerugian lingkungan mengacu kepada empat model, yaitu model abstract endangerment, concrete endangerment, concrete harm, dan serious environmental pollution. Model abstract endangerment mengkriminalisasi kerusakan/ pencemaran lingkungan secara tidak langsung. Keberadaan hukum pidana hanya sebagai pelengkap sistem keputusan -keputusan administrasi yang sudah ada terkait jumlah dan kualitas emisi yang dibuang ke media lingkungan. Hukum pidana membatasi pada penegakan hukum administrasi yang telah ada sebelumnya. Kriminalisasi menurut model ini hanya ditujukan kepada pelanggaran terhadap kewajiban-kewajiban administrasi. ${ }^{15}$ Hukum pidana hanya menambahkan mekanisme penegakan hukum yang tersedia untuk memastikan kepatuhan terhadap pemantauan, perizinan, dan aturan hukum lain yang mengatur aktivitas produksi terkait polusi. Hukum pidana berdasarkan model ini pada umumnya berisi pernyataan umum bahwa setiap orang yang melanggar ketentuan tentang perbuatan, regulasi, atau izin yang dikeluarkan dipidana. Hukum pidana baru diterapkan segera setelah dilakukannya pelanggaran administrasi, meskipun kerugian nyata atau ancaman kerugian dari pelanggaran tersebut belum terjadi. Model abstract endangerment, dengan demikian, dibatasi hanya pada tindak pidana-tindak pidana yang tidak melibatkan kontak langsung

\footnotetext{
${ }^{14}$ Matthew B. Miles dan A. Michael Huberman, Analisis Data Kualitatif, tanpa Penerbit, tt, hlm 16-20.

${ }^{15}$ M. Faure \& M. Nisser, 2017, "How to Punish Environmental Pollution- Some Reflections on the Various Models of Criminalization of Environmental Harm", European Journal of Crime, Criminal Law and Criminal Justice, 3, 1995, hlm. 319. Michael Faure, "The Revolution in Environmental Criminal Law in Europe", Virginia Environmental Law Journal, 35, hlm. 334.
} 
antara bahan tercemar dengan lingkungan. ${ }^{16}$

Menurut model ini, regulasi administrasi merupakan instrumen yang penting dalam mencegah kerusakan lingkungan, sedangkan izin digunakan untuk memastikan bahwa para pemegang izin merupakan orang-orang bermutu. Standar lingkungan seperti standar emisi juga merupakan hal penting untuk memastikan kualitas lingkungan yang berkesinambungan. ${ }^{17}$ Model abstract endangerment fokus pada mempertahankan nilai-nilai administrasi, dan oleh karenanya, kriminalisasi dalam model ini secara tidak langsung melindungi nilai-nilai ekologis. Perbuatan-perbuatan dalam model ini dilarang semata-mata untuk mencegah kerugian lingkungan. Pejabat-pejabat administrasi dapat memonitor suatu kegiatan untuk memastikan bahwa kerugian tidak terjadi apabila aturan-aturan administrasi diikuti. ${ }^{18}$

Model abstract endangerment berbasis kepada kebijakan lingkungan yang mengutamakan pendekatan perintah dan kontrol perizinan. Pejabat administrasi di dalam sistem ini memainkan peranan yang krusial karena mereka yang menentukan jumlah polusi yang diperbolehkan dibuang ke media lingkungan. Mereka juga yang menetapkan standar emisi melalui penggunaan izin. ${ }^{19}$ Model ini juga merupakan kecenderungan dari kombinasi penggunaan hukum publik dan hukum privat terhadap pencegahan kerusakan/pencemaran lingkungan hidup. ${ }^{20}$

Tindak pidana-tindak pidana yang masuk ke dalam model abstract endangerment meliputi tiga kategori. Pertama adalah tindak pidana terkait operasionalisasi suatu kegiatan tanpa izin seperti melakukan kegiatan tanpa izin, melanggar persyaratan monitoring atau inspeksi, atau pelanggaran terhadap peraturan administrasi lain yang tidak terkait dengan kerugian atau ancaman kerugian terhadap lingkungan. Kedua adalah tindak pidana terkait pelanggaran aturan kerja atau menghalang-halangi monitoring atau inspeksi fasilitas. Ketiga adalah tindak pidana yang terkait pelanggaran terhadap Undang-undang, peraturan atau izin yang tidak

\footnotetext{
16Susan F. Mandiberg \&Michael G. Faure, 2009, “A Graduated Punishment Approach to Environmental Crimes: Beyond Vindication of Administrative Authority in the United States and Europe", Columbia Journal of Environmental Law, 34, hlm. 454-455.

${ }_{17}$ Michael Faure \& Jing Liu, 2011-2012, “New Models for the Compensation of Natural Resources”, Kentucky Journal of Equine, Agriculture, and Natural Resources Law, 4, hlm. 265.

18 Susan F. Mandiberg \&Michael G. Faure, a Graduate... Op. Cit., hlm. 455-456.

${ }^{19}$ Michael G. Faure, Ingeborg M. Koopmans, \& Johannes C. Oudijk, 1996, “Imposing Criminal Liability on Government Officials under Environmental Law: A Legal and Economic Analysis", Loyola of Los Angeles International and Comparative Law Journal, 18, hlm. 529.

${ }^{20}$ Gerrit Betlem and Michael Faure, 1998, “Environmental Toxic Torts in Europe: Some Trends in Recovery of Soil Clean-Up Costs and Damages for Personal Injury in the Netherlands, Belgium, England and Germany", Georgetown International Environmental Law Review, 10, hlm. 887.
} 
melibatkan emisi, pelepasan limbah, atau ancaman langsung yang lain terhadap lingkungan. ${ }^{21}$ Model concrete endangerment merujuk kepada fakta bahwa beberapa jenis bahaya/ancaman terhadap nilai-nilai lingkungan melalui penetapan adanya ancaman nyata terhadap lingkungan sebagai prasyarat pertanggungjawaban pidana. Bahaya/ancaman yang abstrak belum memadai untuk adanya pertanggungjawaban pidana karena dianggap sangat abstrak. Model ini tidak mensyaratkan bahwa kerugian nyata harus dibuktikan, tapi cukup pada pembuktian adanya ancaman kerugian dan perbuatan dilakukan secara melawan hukum. ${ }^{22}$ Kriminalisasi dalam model ini dilakukan untuk mencegah timbulnya kerugian baik pada manusia maupun lingkungan. ${ }^{23}$

Model kriminalisasi berbasis concrete endangerment menekankan pada dua hal. Pertama adalah emisi atau polusi dapat menyebabkan ancaman kerugian dan itu perlu dibuktikan. Kedua adalah emisi atau polusi dilakukan secara melawan hukum. Sepanjang aturan-aturan administrasi diikuti, perbuatan tidak dianggap sebagai tindak pidana apabila dilakukan secara sah. Perbuatan tersebut dikategorikan sebagai tindak pidana apabila dilakukan secara melawan hukum dan dapat menyebabkan timbulnya ancaman bahaya. ${ }^{24}$ Model ini sebenarnya melindungi nilai-nilai ekologis secara langsung, tapi keberadaanya tetap bergantung kepada peraturan-peraturan administrasi, ${ }^{25}$ dalam arti model ini masih menggantungkan sepenuhnya kepada prosedur administrasi untuk menetapkan suatu tindak pidana.

Model concrete endangerment memuat dua variasi, yaitu presumed endangerment dan demonstrated endangerment. Undang-undang lingkungan dalam variasi presumed endangerment mengkriminalisasi kontak secara tidak sah beberapa jumlah bahan tercemar dengan lingkungan dengan asumsi bahwa kontak tersebut paling tidak dapat menyebabkan beberapa ancaman bahaya. Pejabat administrasi dalam konteks ini hanya perlu menunjukkan bahwa pembuangan emisi tidak berizin telah dilakukan baik disebabkan oleh fasilitas pembuangan yang tidak berizin sama sekali atau sebenarnya pembuangan emisi diperbolehkan karena telah memperoleh izin, tapi jumlahnya melebihi jumlah yang diperbolehkan sebagaimana tertuang dalam izin. Variasi pertama ini paling mudah pembuktiannya dan memungkinkan lebih seringnya intervensi pemerintah. Bentuk-bentuk tindak pidana dalam variasi yang pertama ini

\footnotetext{
${ }^{21}$ Susan F. Mandiberg \&Michael G. Faure, A Graduated Punishment... Op. Cit., hlm. 457-459.

${ }^{22}$ Michael Faure, Towards a New Model... Op. Cit., hlm. 197. Bandingkan dengan Hartiwiningsih, 2008, Hukum Lingkungan dalam Perspektif Kebijakan Hukum Pidana, UNS Press, Surakarta, hlm 370.

${ }^{23}$ Zachary Hoskins, 2018, "Criminalization and the Collateral Consequences of Conviction", Criminal Law and Philosophy, 12, hlm. 634.

${ }^{24}$ Michael Faure, the Revolution... Op. Cit., hlm. 335.

${ }^{25}$ Byung-Sun Cho, 2000/2001, “Emergence of an International Environmental Criminal Law?" UCLA Journal of Environmental Law and Policy, 19, hlm. 22-23.
} 
berupa pelepasan/ pembuangan limbah ke air atau udara yang bertentangan dengan peraturan administrasi, membuang limbah ke media lingkungan tanpa izin, dan membuang limbah ke media lingkungan dengan melanggar batas jumlah yang ditetapkan dalam izin. Tindak pidana tersebut tidak membutuhkan bukti berupa kerugian nyata atau ancaman kerugian terhadap lingkungan, tetapi cukup adanya kontak antara bahan tercemar dengan lingkungan. ${ }^{26}$

Undang-undang yang menganut variasi demonstrated endangerment mensyaratkan bukti yang jelas tentang suatu ancaman terhadap lingkungan. Hal yang tidak cukup apabila pembuangan emisi ke media lingkungan dilakukan secara melawan hukum. Persyaratan bukti yang jelas inilah yang membedakan Undang-undang dalam variasi ini dengan variasi presumed endangerment. Tindak pidana-tindak pidana dalam variasi demonstrated endangerment juga masuk dalam model concrete endangerment, tapi pembuktian terhadap suatu tindak pidana lebih berat. Contoh tindak pidana dalam variasi ini adalah larangan bagi setiap orang yang secara tidak sah membuang limbah ke air permukaan, tanah atau laut di mana perbuatan atau reaksinya menyebabkan efek yang merugikan, meskipun sementara, terhadap fauna dan flora. ${ }^{27}$

Model concrete harm sebenarnya sama dengan model concrete endangerment bahwa keduanya mensyaratkan pembuktian bahwa pelaku delik lingkungan melanggar peraturan atau prosedur administrasi. Model ini, dengan kata lain, masih belum melepaskan hukum pidana dari ketergantungan administratif. Kerugian lingkungan dalam concrete harm harus berupa kerugian lingkungan secara nyata, dan tidak cukup hanya berupa ancaman kerugian. ${ }^{28}$ Problem yang muncul dalam model ini adalah menentukan makna kerugian lingkungan dan hubungan kausalitas.

Makna kerugian lingkungan bergantung kepada pendekatan yang digunakan. Pendekatan tradisional memandang bahwa kerugian lingkungan dibatasi pada kerugian yang dialami oleh manusia seperti ancaman atau kerugian terhadap kesehatan dan keamanan manusia. Pendekatan ini masih menggantungkan hukum lingkungan kepada hukum pidana tradisional yang membatasi manusia sebagai korban. Kerugian lingkungan juga dapat dikaji dari pendekatan ekologis. Secara spesifik kerugian lingkungan berupa kerusakan dan degradasi ekosistem, kepunahan spesies, perubahan cuaca dan pemanasan global, pencemaran lingkungan, dan kerugian terhadap binatang. ${ }^{29}$ Kerusakan/pencemaran lingkungan dalam

\footnotetext{
${ }^{26}$ Susan F. Mandiberg \&Michael G. Faure, A Graduated Punishment... Op. Cit., hlm. 460-464.

${ }^{27}$ Ibid., hlm. 465-468.

28 Ibid., hlm. 469.

${ }^{29}$ Jan G. Laitos, Standing and Environmental Harm... Op. Cit., hlm. 67-71.
} 
perspektif antropologi dapat menyebabkan kerugian terhadap nilai-nilai budaya suatu masyarakat. Istilah yang disematkan terhadap fenomena ini adalah polusi budaya yang merupakan imbas dari kerja buruk lingkungan dan pornografi. ${ }^{30}$

Kerugian lingkungan juga dilihat dari pendekatan ekonomi (mikro). Menurut pendekatan ini, penentuan berapa kerugian lingkungan baik terhadap manusia maupun terhadap lingkungan dihitung berdasarkan konsep maksimalisasi kesejahteraan sosial. Secara operasional, konsep terkait jumlah keuntungan yang diperoleh pelaku dari melakukan tindak pidana lingkungan, dikurangi kerugian yang disebabkan oleh perbuatan itu dan pengeluaran dalam rangka penegakan hukum. ${ }^{31}$ Kerugian dimaksud meliputi kerugian faktual yang dialami oleh negara secara langsung akibat perbuatan pelaku yang menimbulkan pencemaran/kerusakan lingkungan, biaya yang harus dikeluarkan korban potensial untuk mencegah agar tidak menjadi korban, biaya yang secara perhitungan ekonomi diprediksikan akan dialami oleh masyarakat dan harus ditanggung negara, dan biaya penegakan hukum seperti biaya pengungkapan kasus, biaya penyidikan, penuntutan, persidangan, dan pelaksanaan pidana. 32

Model concrete harm mensyaratkan pembuktian bahwa perbuatan yang dilarang telah menimbulkan kerugian lingkungan. Hal yang tidak cukup jika yang dibuktikan hanya sekedar ancaman kerugian lingkungan. Model ini meniscayakan pembuktian sebab akibat yang dalam hukum pidana disebut ajaran kausalitas. Inti ajaran ini terkait perbuatan mana yang harus dianggap sebagai penyebab dari timbulnya akibat yang dilarang hukum. Setelah diketahui bahwa perbuatan tertentulah yang merupakan sebab bagi timbulnya akibat, maka hal demikian berguna untuk menentukan siapakah yang harus bertanggung jawab atas sesuatu hal yang ternyata diketahui sebagai sebab atas timbulnya akibat yang dilarang oleh hukum.

Ahmad Sofian dengan mengutip pendapat Barda Nawawi Arief mengatakan bahwa ada dua sisi ajaran kausalitas, yaitu ajaran kausalitas yang subjektif dan ajaran kausalitas yang objektif. Hal yang pertama adalah mencari hubungan kausal antara orang yang melakukan perbuatan dengan perbuatannya. Ajaran yang pertama ini biasanya masuk dalam teori kesalahan atau teori untuk menentukan sikap batin jahat. Hal yang kedua adalah mencari hubungan kausal antara perbuatan dan akibat dari perbuatan itu. Ajaran yang kedua ini

\footnotetext{
${ }^{30}$ John Copeland Nagle, 2009, “The Idea of Pollution”, U.C. Davis Law Review, 43, hlm. 2.

${ }^{31}$ Nuno Garoupa \& Daniel Klerman, 2002, “Optimal Law Enforcement with a Rent-Seeking Government”, American Law and Economics Review, hlm. 116-117.

${ }^{32}$ Mark A. Cohen, 2000, “The Economics of Crime and Punishment: Implications for Sentencing of Economic Crime and New Technology Offences", George Mason Law Review, hlm. 506-507.
} 
digunakan untuk menemukan perbuatan melawan hukum yang menimbulkan akibat yang dilarang. ${ }^{33}$ Delik-delik yang memerlukan ajaran kausalitas ini berupa delik materil, delik-delik omisi yang menimbulkan akibat, dan delik yang dikualifikasi oleh akibatnya. Teori-teori mengenai ajaran kausalitas yang berkembang dalam hukum pidana meliputi teori conditio sine qua non, ajaran menggeneralisir baik dalam bentuk adequat subjektif maupun adequat objektif, ajaran mengindividualisir, dan teori relevansi. ${ }^{34}$ Tidak ada satu dari teori-teori tersebut yang dapat digunakan untuk semua perkara pidana dalam konteks menemukan sebab bagi timbulnya akibat dalam kasus-kasus yang muncul karena penyebab bisa sederhana, tunggal atau bahkan banyak dan kompleks.

Kausalitas dalam tindak pidana lingkungan tidak terlalu sulit apabila timbulnya kerusakan/pencemaran lingkungan disebabkan oleh satu perbuatan. Persoalan kausalitas menjadi sulit ketika penyebab bagi timbulnya kerugian lingkungan banyak, berantai, dan kompleks. Dalam kasus-kasus pidana konvensional seperti pembunuhan, pembuktian kausalitas merupakan hal yang sangat sulit, apalagi dalam perkara pencemaran lingkungan yang melibatkan banyak sekali variabel. Kondisi ini tentu memunculkan tantangan tersendiri bagi penuntut umum untuk menemukan dan menentukan suatu perbuatan sebagai sebab bagi timbulnya kerugian lingkungan. ${ }^{35}$ Terlepas dari itu semua, model concrete harm dan juga model serious environmental pollution yang dijelaskan berikut ini mensyaratkan adanya pembuktian kausalitas.

Model serious environmental pollution sudah melepaskan diri sepenuhnya dari ketergantungan administratif hukum pidana yang ditandai dengan dua ciri. Pertama adalah eliminasi izin sebagai pelindung. Sekalipun seseorang telah memiliki izin dari pejabat administrasi, jika perbuatannya menimbulkan kerugian serius terhadap lingkungan, maka perbuatan tersebut tetap dikategorikan sebagai tindak pidana. Kedua adalah eliminasi sifat melawan hukum sebagai elemen tindak pidana lingkungan. Hukum pidana tetap dapat digunakan apabila menimbulkan kerugian sangat serius sekalipun perbuatan tidak melawan hukum, dalam arti dilakukan sesuai dengan persyaratan izin atau peraturan administratif. ${ }^{36}$

Perbuatan-perbuatan yang dikriminalisasi berdasarkan model ini masih berkaitan dengan emisi, tapi akibat yang ditimbulkan lebih serius seperti polusi yang berkepanjangan,

\footnotetext{
${ }^{33}$ Ahmad Sofian, 2018, Ajaran Kausalitas Hukum Pidana, Prenada Media, Jakarta, hlm. 140-141.

${ }^{34}$ Ibid., hlm. 105-118.

${ }^{35}$ Susan F. Mandiberg \&Michael G. Faure, A Graduated Punishment... Op. Cit., hlm. 478.

${ }^{36}$ Ibid., hlm. 481-485.
} 
akibat serius terhadap kesehatan manusia, dan/atau luka yang parah terhadap penduduk. ${ }^{37}$ Model ini bertujuan mengkriminalisasi kerusakan/pencemaran lingkungan yang sangat serius tanpa melihat apakah hal itu disebabkan oleh pelanggaran administrasi. Sekalipun pembuat delik telah mematuhi izin dan persyaratan-persyaratannya serta peraturan administratif lainnya, tetap saja perbuatan tersebut dikategorikan sebagai tindak pidana apabila menimbulkan akibat yang serius terhadap lingkungan. ${ }^{38}$

\section{Aktualisasi Model Kriminalisasi Berbasis Kerugian Lingkungan Dalam UU PPLH}

$\mathrm{D}$ elik-delik dalam UU PPLH kebanyakan terkait pelanggaran terhadap kewajiban administrasi seperti pelanggaran terhadap izin sehingga bergantung kepada pemenuhan persyaratan yang ditetapkan oleh atau ketentuan yang terkandung dalam peraturan administratif (administrative dependent crime). 39 Delik-delik yang yang keberadaannya bergantung kepada peraturan administratif dalam UUPPLH sebagai berikut:

a. Melanggar baku mutu air limbah, baku mutu emisi, atau baku mutu gangguan (Pasal 100 ayat 1$)$;

b. Melepaskan dan/atau mengedarkan produk rekayasa genetik ke media lingkungan hidup yang bertentangan dengan peraturan perUndang-undangan atau izin lingkungan (Pasal 101);

c. Melakukan pengelolaan limbah B3 tanpa izin dari Menteri, gubernur, atau bupati/walikota sesuai dengan kewenangannya (Pasal 102);

d. Menghasilkan limbah B3 dan tidak melakukan pengelolaan (Pasal 103);

e. Melakukan dumping limbah dan/atau bahan ke media lingkungan hidup tanpa izin (Pasal 104);

f. Memasukkan B3 yang dilarang menurut peraturan perundang-undangan ke dalam wilayah Negara Kesatuan Republik Indonesia (Pasal 107);

g. Melakukan usaha dan/atau kegiatan tanpa memiliki izin lingkungan (Pasal 109);

h. Menyusun amdal tanpa memiliki sertifikat kompetensi penyusun amdal (Pasal 110);

i. Menerbitkan izin lingkungan tanpa dilengkapi dengan amdal atau UKL-UPL (Pasal 111 ayat 1$)$;

\footnotetext{
${ }^{37}$ Michael Faure, the Revolution... Op. Cit., hlm. 335-336.

38 Susan F. Mandiberg \&Michael G. Faure, A Graduated Punishment... Op.Cit., hlm. 480.

${ }^{39}$ D. Schaffmeister, 1994, "Perlindungan Hukum Pidana atas Obyek-obyek Lingkungan Hidup" dalam D. Schaffmeister dkk, Kekhawatiran Masa Kini Pemikiran Mengenai Hukum Pidana Lingkungan dalam Teori E Praktik, Diterjemahkan Oleh Tristan P. Moeliono, PT. Citra Aditya Bakti, Bandung, hlm. 159.
} 
j. Menerbitkan izin usaha dan/atau kegiatan tanpa dilengkapi dengan izin lingkungan (Pasal 111 ayat 2);

k. Dengan sengaja tidak melakukan pengawasan terhadap ketaatan penanggung jawab usaha dan/atau kegiatan terhadap peraturan perundang-undangan dan izin lingkungan yang mengakibatkan terjadinya pencemaran dan/atau kerusakan lingkungan yang mengakibatkan hilangnya nyawa manusia (Pasal 112); dan

1. Penanggung jawab usaha dan/atau kegiatan yang tidak melaksanakan paksaan pemerintah (Pasal 114).

Delik-delik tersebut dikategorikan ke dalam administrative dependent crime karena tiga alasan. Pertama adalah bahwa delik-delik tersebut merupakan delik formil yang sasarannya adalah pada dilakukannya perbuatan yang dilarang, dan bukan pada akibatnya. Kedua adalah bahwa perbuatan yang dilarang bukan karena sifatnya yang tercela, melainkan karena dilarang oleh Undang-undang (legally wrong). Ketiga adalah bahwa esensi delik dalam pasal-pasal tersebut berkaitan dengan pelanggaran terhadap izin sehingga nuansa administratifnya lebih kental. Seseorang diwajibkan untuk memenuhi persyaratan-persyaratan tertentu agar bisa melakukan tindakan tertentu. Pelanggaran terhadap persyaratan ini dikategorikan sebagai tindak pidana dan diancam dengan sanksi pidana. ${ }^{40}$

UU PPLH juga mengatur delik yang keberadaannya sudah melepaskan diri sepenuhnya dari ketergantungan administratif hukum pidana. Delik ini sudah terjadi meskipun persyaratan/kewajiban administratif tidak melanggar sepanjang telah menimbulkan kerusakan/pencemaran lingkungan. Delik-delik yang digolongkan sebagai administrative independent crimes dalam UU PPLH sebagai berikut:

a. Dengan sengaja melakukan perbuatan yang mengakibatkan dilampauinya baku mutu udara ambien, baku mutu air, baku mutu air laut, atau kriteria baku kerusakan lingkungan hidup (Pasal 98 ayat 1);

b. Dengan sengaja melakukan perbuatan yang mengakibatkan dilampauinya baku mutu udara ambien, baku mutu air, baku mutu air laut, atau kriteria baku kerusakan lingkungan hidup yang mengakibatkan orang luka dan/atau bahaya kesehatan manusia (Pasal 98 ayat 2);

c. Dengan sengaja melakukan perbuatan yang mengakibatkan dilampauinya baku mutu 
udara ambien, baku mutu air, baku mutu air laut, atau kriteria baku kerusakan lingkungan hidup yang mengakibatkan orang mengalami luka berat atau mati (Pasal 98 ayat 3);

d. Karena kelalaiannya melakukan perbuatan yang mengakibatkan dilampauinya baku mutu udara ambien, baku mutu air, baku mutu air laut, atau kriteria baku kerusakan lingkungan hidup (Pasal 99 ayat 1);

e. Karena kelalaiannya melakukan perbuatan yang mengakibatkan dilampauinya baku mutu udara ambien, baku mutu air, baku mutu air laut, atau kriteria baku kerusakan lingkungan hidup yang mengakibatkan orang luka dan/atau bahaya kesehatan manusia (Pasal 99 ayat 2);

f. Karena kelalaiannya melakukan perbuatan yang mengakibatkan dilampauinya baku mutu udara ambien, baku mutu air, baku mutu air laut, atau kriteria baku kerusakan lingkungan hidup yang mengakibatkan orang mengalami luka berat atau mati (Pasal 99 ayat 3);

g. Memasukkan limbah ke dalam wilayah Negara Kesatuan Republik Indonesia yang berasal dari luar wilayah Negara Kesatuan Republik Indonesia ke media lingkungan hidup Negara Kesatuan Republik Indonesia (Pasal 105);

h. Memasukkan Limbah Bahan Berbahaya dan Beracun (B3) ke dalam wilayah Negara Kesatuan Republik Indonesia (Pasal 106);

i. Melakukan pembakaran lahan (Pasal 108);

j. Memberikan informasi palsu, menyesatkan, menghilangkan informasi, merusak informasi, atau memberikan keterangan yang tidak benar yang diperlukan dalam kaitannya dengan pengawasan dan penegakan hukum yang berkaitan dengan perlindungan dan pengelolaan lingkungan hidup (Pasal 113); dan

k. Sengaja mencegah, menghalang-halangi, atau menggagalkan pelaksanaan tugas pejabat pengawas lingkungan hidup dan/atau pejabat penyidik pegawai negeri sipil (Pasal 115).

Delik-delik dalam Pasal 98, Pasal 99, Pasal 105, Pasal 106, dan Pasal 108 tersebut merupakan delik yang tidak bergantung kepada pelanggaran administratif karena menimbulkan atau dapat menimbulkan pencemaran atau kerusakan terhadap lingkungan hidup yang berbahaya bagi kelangsungan hidup manusia dan lingkungan hidup. Delik-delik tersebut lebih memiliki nuansa perlindungan terhadap daya dukung dan daya tampung 
lingkungan. ${ }^{41}$ Delik-delik dalam Pasal 113 dan Pasal 115 merupakan perbuatan tercela secara moral. Meskipun perbuatan tersebut tidak dilarang oleh UU, tetap saja perbuatan tersebut tercela secara moral dan bertentangan dengan nilai-nilai yang ada dalam masyarakat (morally wrong).

Dalam konteks model kriminalisasi berbasis kerugian lingkungan, delik-delik dalam UU PPLH dapat dipetakan berdasarkan model tersebut yang uraiannya sebagai berikut. Perbuatan-perbuatan yang dikriminalisasi dalam model abstract endangerment tidak menimbulkan kerugian atau ancaman kerugian lingkungan karena hanya ditujukan kepada pelanggaran terhadap kewajiban-kewajiban administrasi. ${ }^{42}$ Kriminalisasi dalam model ini juga tidak substansial dalam kaitannya dengan tujuan yang hendak dicapai oleh negara. Alasan bahwa perbuatan-perbuatan dalam model ini terkait upaya mencegah kerusakan/pencemaran lingkungan hidup juga tidak memadai karena esensi tindak pidana tersebut tidak melibatkan kontak langsung antara bahan tercemar dengan lingkungan.

Delik-delik dalam UU PPLH yang masuk dalam model abstract endangerment berupa; a) melakukan usaha dan/atau kegiatan (UKL-UPL) tanpa memiliki izin lingkungan (Pasal 109); c) menyusun amdal tanpa memiliki sertifikat kompetensi penyusun amdal (Pasal 110);) dan d) menerbitkan izin lingkungan tanpa dilengkapi dengan UKL-UPL atau menerbitkan izin usaha dan/atau kegiatan tanpa dilengkapi dengan izin lingkungan (Pasal 111). Esensi dari perbuatan-perbuatan tersebut sebenarnya berkaitan dengan pelanggaran terhadap kewajibankewajiban administrasi atau pelanggaran izin, tidak mengancam terhadap kerusakan/ pencemaran lingkungan, dan tidak melibatkan emisi atau pelepasan limbah.

Kriminalisasi pada model concrete endangerment cukup mensyaratkan pada pembuktian adanya ancaman kerugian dan perbuatan dilakukan secara melawan hukum. ${ }^{43}$ Berbeda dengan model abstract endangerment, model ini meniscayakan kontak langsung antara bahan tercemar dengan lingkungan. ${ }^{44}$ Perbuatan-perbuatan yang dikriminalisasi berkaitan dengan emisi atau polusi yang dibuang ke media lingkungan yang dilakukan secara melawan hukum seperti melanggar izin meskipun belum menimbulkan kerusakan/pencemaran lingkungan. Pejabat administrasi dalam konteks ini hanya perlu menunjukkan bahwa pembuangan emisi

\footnotetext{
41Syahrul Machmud, 2012, Problematika Penerapan Delik Formil dalam Perspektif Penegakan Hukum Pidana Lingkungan di Indonesia Fungsionalisasi Azas Ultimum Remedium sebagai Pengganti Azas Subsidiaritas, Mandar Maju, Bandung, hlm. 243.

${ }^{42}$ M. Faure \& M. Nisser, Haw to Punish.... Op. Cit., hlm. 323.

${ }^{43}$ Michael Faure, 2008, "Towards a New Model of Criminalization... Op. Cit., hlm. 197. Bandingkan dengan Hartiwiningsih, Hukum Lingkungan dalam Perspektif Kebijakan Hukum Pidana, UNS Press, Surakarta, hlm 370.

${ }^{44}$ Susan F. Mandiberg \&Michael G. Faure, A Graduated Punishment... Op. Cit., hlm. 460-464.
} 
tidak berizin telah dilakukan baik disebabkan oleh fasilitas pembuangan yang tidak berizin atau sebenarnya pembuangan emisi diperbolehkan karena telah memperoleh izin, tapi jumlahnya melebihi jumlah yang diperbolehkan sebagaimana tertuang dalam izin.

Bentuk-bentuk tindak pidana dalam UU PPLH yang masuk ke dalam model concrete endangerment, yaitu; a) melepaskan dan/atau mengedarkan produk rekayasa genetik ke media lingkungan hidup yang bertentangan dengan izin lingkungan (Pasal 101); b) melanggar baku mutu air limbah, baku mutu emisi, atau baku mutu gangguan (Pasal 100); c) melakukan pengelolaan limbah B3 tanpa izin (Pasal 102); d) menghasilkan limbah B3 dan tidak melakukan pengelolaan (Pasal 103); dan e) melakukan dumping limbah dan/atau bahan ke media lingkungan hidup tanpa izin (Pasal 104). Esensi dari tindak pidana-tindak pidana tersebut memenuhi kriteria model kriminalisasi berbasis concrete endangerment karena ada kontak antara bahan tercemar dengan lingkungan yang mengancam kerusakan/pencemaran lingkungan, dan kontak tersebut dilakukan secara melawan hukum dalam bentuk tanpa izin atau melanggar peraturan atau kewajiban administrasi. 45

Kriminalisasi pada model concrete harm mensyaratkan bahwa kerugian lingkungan harus berupa kerugian lingkungan secara nyata ${ }^{46}$ sehingga mutlak memerlukan pembuktian hubungan kausalitas (hubungan sebab-akibat). Tindak pidana dalam UU PPLH yang masuk ke dalam model kriminalisasi berbasis concrete harm diatur dalam Pasal 112 yaitu, pejabat berwenang yang dengan sengaja tidak melakukan pengawasan terhadap ketaatan penanggung jawab usaha dan/atau kegiatan terhadap peraturan perundang-undangan dan izin lingkungan yang mengakibatkan terjadinya pencemaran dan/atau kerusakan lingkungan yang mengakibatkan hilangnya nyawa manusia. Meskipun pasal ini mensyaratkan adanya kerugian aktual pencemaran dan/atau kerusakan lingkungan dan hilangnya nyawa manusia, tapi keberadaannya tetap masih berupa ketergantung administratif hukum pidana. Frase '...terhadap peraturan perundang-undangan dan izin lingkungan...' membuktikan hal itu.

Kriminalisasi pada model serious environmental pollution sudah melepaskan diri sepenuhnya dari ketergantungan administratif hukum pidana. Hukum pidana tetap dapat digunakan apabila menimbulkan kerugian lingkungan serius sekalipun perbuatan tidak melawan hukum, dalam arti dilakukan sesuai dengan persyaratan izin atau peraturan administratif. Model ini bertujuan mengkriminalisasi kerusakan/pencemaran lingkungan yang sangat serius tanpa melihat apakah hal itu disebabkan oleh pelanggaran administrasi.

\footnotetext{
45 Susan F. Mandiberg, Locating the Environmental Harm... Op. Cit., hlm. 1196.

46 Susan F. Mandiberg \&Michael G. Faure, A Graduated Punishment... Op. Cit., hlm. 469.
} 
Sekalipun pembuat delik telah mematuhi izin dan persyaratan-persyaratannya serta peraturan administratif lainnya, tetap saja perbuatan tersebut dikategorikan sebagai tindak pidana apabila menimbulkan akibat yang serius terhadap lingkungan. ${ }^{47}$

Tindak pidana yang masuk dalam model serious environmental pollution dalam UU PPLH antara lain; a) dengan sengaja melakukan perbuatan yang mengakibatkan dilampauinya baku mutu udara ambien, baku mutu air, baku mutu air laut, atau kriteria baku kerusakan lingkungan hidup (Pasal 98 ayat 1); b) melakukan perbuatan sebagaimana dimaksud dalam Pasal 98 ayat (1) yang mengakibatkan orang luka dan/atau bahaya kesehatan manusia (Pasal 98 ayat 2); c) melakukan perbuatan sebagaimana dimaksud dalam Pasal 98 ayat (1) yang mengakibatkan orang luka berat atau mati (Pasal 98 ayat 3); d) karena kelalaiannya mengakibatkan dilampauinya baku mutu udara ambien, baku mutu air, baku mutu air laut, atau kriteria baku kerusakan lingkungan hidup (Pasal 99 ayat 1); e) melakukan perbuatan sebagaimana dimaksud dalam Pasal 99 ayat (1) yang mengakibatkan orang luka dan/atau bahaya kesehatan manusia (Pasal 99 ayat 2); f) melakukan perbuatan sebagaimana dimaksud dalam Pasal 99 ayat (1) yang mengakibatkan orang luka berat atau mati (Pasal 99 ayat 3); g) dan melakukan pembakaran lahan (Pasal 108). Semua bentuk tindak pidana tersebut memenuhi kriteria dalam model ini karena sudah melepaskan diri dari ketergantungan administratif hukum pidana dan timbulnya kerugian lingkungan baik berupa kerusakan maupun pencemaran lingkungan harus dibuktikan.

Delik berupa 'memasukkan limbah ke dalam wilayah Negara Kesatuan Republik Indonesia' (Pasal 105), 'memasukkan limbah B3 ke dalam wilayah Negara Kesatuan Republik' (Pasal 106), dan 'melakukan pembakaran lahan' (Pasal 108) juga perlu dimasukkan ke dalam model serious environmental pollution. Substansi kedua bentuk delik ini sebenarnya sudah mengeliminasi ketergantung administratif hukum pidana meskipun pembuktian sebab akibat (kausalitas) tidak diperlukan karena delik dirumuskan secara formil. Perumusan delik secara formil sebenarnya berbeda dengan model serious environmental pollution yang dikemukakan oleh Faure. Menurut peneliti, hal demikian sudah masuk ke dalam kebijakan suatu negara untuk memformulasikan delik-delik yang dianggap serius terhadap lingkungan hidup. Artinya, secara prinsip, delik-delik dalam pasal 105, Pasal 106, dan Pasal 108 dapat dikelompokkan ke dalam model serious environmental pollution sekalipun dirumuskan sebagai delik formil. Perumusan delik semacam ini berimplikasi kepada ancaman sanksi pidana yang harus lebih ringan dibandingkan delik-delik dalam model ini yang dirumuskan sebagai delik

47 Ibid., hlm. 480. 
materil.

\section{PENUTUP}

\section{Kesimpulan}

$\mathrm{D}$

iskursus teoritik tentang model-model kriminalisasi berbasis kerugian lingkungan hidup mengacu kepada empat model yang selama ini berkembang, yaitu model bahaya abstrak (abstract endangerment), bahaya nyata (concrete endangerment), kerugian nyata (concrete harm), dan polusi lingkungan yang serius (serious environmental pollution). Pada ketiga model pertama, hukum pidana masih belum melepaskan diri dari ketergantung administratif (administrative dependent), sedangkan pada model terakhir, hukum pidana sudah melepaskan diri dari ketergantungan administratif (administrative independent). Hukum pidana tetap dapat digunakan apabila menimbulkan kerugian sangat serius sekalipun perbuatan tidak melawan hukum, dalam arti dilakukan sesuai dengan persyaratan izin atau peraturan administratif.

Model-model kriminalisasi berbasis kerugian lingkungan teraktualisasi dalam UU PPLH. Delik-delik dalam UU PPLH yang masuk dalam model abstract endangerment tercantum dalam Pasal 109, Pasal 110, dan Pasal 111. Delik-delik dalam UU tersebut yang masuk ke dalam model concrete endangerment dirumuskan dalam Pasal 101, Pasal 100 ayat (1), Pasal 102, Pasal 103, dan Pasal 104. Delik terkait model concrete harm diatur dalam Pasal 112. Delik-delik yang masuk dalam model serious environmental pollution terlihat pada Pasal 98, Pasal 99, Pasal 105, Pasal 106, dan Pasal 108.

\section{Saran}

Denelitian ini menyarankan perlunya dilakukan penelitian tentang; 1) aktualisasi model-
model kriminalisasi berbasis kerugian lingkungan dalam perundang-undangan sektoral bidang lingkungan hidup; dan 2) sistem pemidanaan dalam perundang-undangan bidang Lingkungan Hidup yang berorientasi kepada pencegahan/pemulihan kerusakan/ pencemaran lingkungan.

\section{DAFTAR PUSTAKA}

\section{Buku}

D. Schaffmeister (Eds.), 1994, Kekhawatiran Masa Kini Pemikiran Mengenai Hukum Pidana Lingkungan dalam Teori \& Praktik, Bandung: PT. Citra Aditya Bakti;

Douglas Husak, 2009, Overcriminalization the Limits of the Criminal Law, New York: Oxford 
University Press;

Faure, M and Niessen, N (Eds.). 2006, Environmental Law in Development Lesson from the Indonesia Experience, UK: Edward Elgar Publishing Limited;

Herbert L. Packer, 1968, the Limits of the Criminal Sanction, California: Stanford University Press, California;

Ibrahim, J, 2006, Teori dan Metodologi Penelitian Hukum Normatif. Malang: BayuMedia Publishing;

Machmud, S, 2012, Problematika Penerapan Delik Formil dalam Perspektif Penegakan Hukum Pidana Lingkungan di Indonesia Fungsionalisasi Azas Ultimum Remedium sebagai Pengganti Azas Subsidiaritas. Bandung: Mandar Maju;

Salman Luthan, 2007, Kebijakan Penal Mengenai Kriminalisasi di Bidang Keuangan, Disertasi, Jakarta: Universitas Indonesia;

Sofian, A, 2018, Ajaran Kausalitas Hukum Pidana. Jakarta: Prenada Media;

Wigjnosoebroto, S, 2002, Hukum, Paradigma, Metode dan Dinamika Masalahnya. Jakarta: HuMa;

Wood, M. C, 2014, Nature's Trust Environmental Law for a New Ecological Age. New York: Cambridge University Press.

\section{Jurnal}

Betlem, G \& Faure, M, 1998, “Environmental Toxic Torts in Europe: Some Trends in Recovery of Soil Clean-Up Costs and Damages for Personal Injury in the Netherlands, Belgium, England and Germany", Georgetown International Environmental Law Review, Vol. 10;

Boer, B, 1995, “Institutionalising Ecologically Sustainable Development: The Roles of National, State, and Local Governments in Translating Grand Strategy into Action", Willamette Law Review, Vol. 31;

Cho, BS, 2001, “Emergence of an International Environmental Criminal Law?” UCLA Journal of Environmental Law and Policy, Vol. 19;

Cohen, M.A, 2000, "The Economics of Crime and Punishment: Implications for Sentencing of Economic Crime and New Technology Offences", George Mason Law Review;

Faure, M \& Liu, J. 2012. New Models for the Compensation of Natural Resources", Kentucky Journal of Equine, Agriculture, and Natural Resources Law, Vol. 4;

Faure, M \& Nisser, M, 1995, “How to Punish Environmental Pollution-Some Reflections on the Various Models of Criminalization of Environmental Harm", European Journal of Crime, Criminal Law and Criminal Justice, Vol. 3; 
Model Kriminalisasi Berbasis Kerugian Lingkungan dan Aktualisasinya dalam Undang-Undang 32 Tahun 2009

Faure, M, 2017, "The Revolution in Environmental Criminal Law in Europe", Virginia Environmental Law Journal, Vol. 35;

Faure, M, Koopmans, I.M, \& Oudijk, J.C, 1996, "Imposing Criminal Liability on Government Officials under Environmental Law: A Legal and Economic Analysis", Loyola of Los Angeles International and Comparative Law Journal, Vol. 18;

Garoupa, N \& Klerman, D, 2002, “Optimal Law Enforcement with a Rent-Seeking Government", American Law and Economics Review;

Green, S.P, 1997, “Why it's a Crime to Tear the Tag off a Mattress; Overcriminalization and The Moral Content of Regulatory Offences", Emory Law Review, Vol. 46;

Hall, M, 2014, “Environmental Harm and Environmental Victims Scouping Out a Green Victimology", International Review of Victimology, Vol. 20;

Hörnle, T, 2016, “Theories of Criminalization", Criminal Law and Philosophy, Vol. 10;

Hoskins, Z, 2018, "Criminalization and the Collateral Consequences of Conviction", Criminal Law and Philosophy, Vol. 12;

Jareborg, Nils, 2005, "Criminalization as Last Resort", Ohio State Journal of Criminal Law;

Laitos, J.G, 2013, "Standing and Environmental Harm: The Double Paradox", Virginia Environmental Law Journal, Vol. 31;

Maguire, R, 2012, “Incorporating International Environmental Legal Principle into Future Climate Change", Carbon \& Climate Law Review, Vol. 6;

Mandiberg, S.F, 2009, “Locating the Environmental Harm in Environmental Crimes, Utah Law Review;

Mandiberg, S.F. \& Faure, M, 2009, “A Graduated Punishment Approach to Environmental Crimes: Beyond Vindication of Administrative Authority in the United States and Europe", Columbia Journal of Environmental Law, Vol. 34;

McGorrery, P, 2018, “The Philosophy of Criminalisation: A Review of Duff et al.'s Criminalisation Series", Criminal Law and Philosophy, Vol. 12;

Miles, M.B dan Huberman, A.M. (tt), 1992, Analisis Data Kualitatif, Jakarta: UI-Press.

Nagle, J.C, 2009, “The Idea of Pollution”, U.C. Davis Law Review, Vol. 43;

Picinali, F, 2017, “The Denial of Procedural Safeguards in Trials for Regulatory Offences: A Justification", Criminal Law and Philosophy, Vol. 11;

Sunstein, C.R, 2006, "Irreversible and Catastrophic”, Cornell Law Review, Vol. 91;

T.S. Aagaard, 2011, “Environmental Harm, Use Conflicts, and Neutral Baselines in Environmental Law", Duke Law Journal, Vol. 60. 